THE PROTECTION OF FUNDAMENTAL RIGHTS IN THE NETHERLANDS AND SOUTH AFRICA COMPARED: CAN THE MANY DIFFERENCES BE JUSTIFIED

ISSN 1727-3781

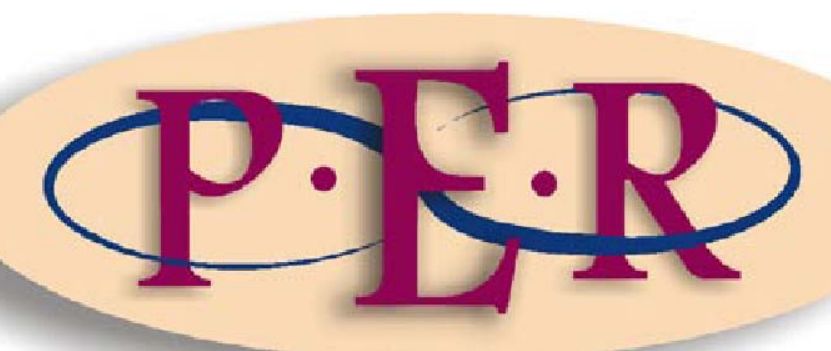

2008 VOLUME 2 


\section{THE PROTECTION OF FUNDAMENTAL RIGHTS IN THE NETHERLANDS AND SOUTH AFRICA COMPARED: CAN THE MANY DIFFERENCES BE JUSTIFIED?}

\section{G van der Schyff*}

\section{Introduction}

The aim of this contribution is to briefly consider and compare the various avenues followed in the Netherlands and South Africa in achieving the desired protection of fundamental rights, and ultimately good governance. These legal systems are chosen as both follow quite different routes to securing such protection, thereby inviting the question whether their different approaches are justified? The comparison will be conducted by comparing both legal systems as to the source of the rights protected, the character of such rights and the loci of protection within each system. But first the idea of fundamental rights protection is explored below in laying the groundwork for comparing the Netherlands and South Africa.

\section{Fundamental rights protection as a common good}

Good governance is increasingly placed on the agenda in modern societies. This is also true as far as the study of law is concerned. Gone are the days when the focus of academic endeavour simply rested on a thorough study of institutions, simply 'governance' if you will. The emphasis has shifted from an interest in how power is created and channelled, to how it should be exercised, hence 'good' governance. ${ }^{1}$

* Dr Gerhard van der Schyff, BA LLB LLM (Rand Afrikaans University) PhD (Antwerp). Lecturer in the Department of Constitutional and Administrative Law, Tilburg University, The Netherlands.

1 See also Hatchard et al Comparative Constitutionalism 2. 
For example, the nineteenth century liberal rechtsstaat may have been a vehicle with which to secure legality, namely the requirement that all state action must have a foundation in law, but it failed to ensure the integrity of the laws passed. ${ }^{2}$ In this regard one only has to recall the Second World War and the atrocities committed which were often sanctioned by some or other law produced by the corrupted German rechtsstaat. ${ }^{3}$ The fact that a norm can technically be identified as a law is no longer good enough. This is also clearly evidenced by the shift after the War to fundamental rights protection as a common good. It was realised, more than ever before, that laws not only had to satisfy the formal requirements of legality, but cardinally also the substantive requirements of legitimacy.

In other words, the liberal rechtsstaat with its emphasis on the technical nature of laws was complemented by a deep concern as to the nature of such laws. This deep concern for the justifiability of the content of laws can be identified as the material rechtsstaat. ${ }^{4}$ The rechtsstaat, declaring the supremacy of law, not only had to ensure that laws were properly passed, but also that they respected certain minimum notions of justice. The latter is something which could no longer be left to the good will and discretion of the designated lawgiver, even if it was democratically legitimated. The 'good society' was no longer simply the concern of politics, but became increasingly a point of debate and contestation before the courts, especially in the form of fundamental rights. ${ }^{5}$

The acceptance of the Universal Declaration of Rights in 1948 set the tone for more awareness and activism in respect of basic rights, not only at the international level but also at the national level, not only in parliament but also

2 Van Eikema Hommes 1978 TSAR 45-46; Zoethout Rechtsstaat 59-60.

3 Stern 1981 TSAR 245-245 speaks in this context of the Rechtsstaat being turned into a Gesetzesstaat. 'Recht' is then intended to mean law as morally justifiable, while 'Gesetz' is intended to mean legal rules devoid of any moral authority.

4 Böckenförde State, Society and Liberty 66-67; Van Eikema Hommes supra n 2 at 46-47; Zoethout supra n 2 at 60-63.

5 Cf Troper 2003 Int'I J of Constitutional Law 99; Cappelletti 1992 TSAR 265-266; Venter Constitutional Comparison 81-84; Adams Recht en Democratie 105-142. 
in court. ${ }^{6}$ This said, it is important to note that different societies approach the prominence of fundamental rights by quite often radically different means. The 'good society' mindful of fundamental rights cannot be achieved by some or other fixed magic formula, but is influenced by various tensions and needs. However, one thing stands clear; there can be no 'good society' without such a thing as 'society'. Good governance by means of fundamental rights protection must aim to defend society against the state. ${ }^{7}$ Freedom is negated where society, as the sum total of human endeavour, is collapsed in the state, as the means with which to govern such endeavour. ${ }^{8}$ This is precisely the justification for fundamental rights, namely constructs aimed at delineating a free society in the face of government regulation and intervention. But although the notion of fundamental rights may be near universal, its practice is quite different, as will transpire below from the experience of the Netherlands and South Africa.

\section{The Netherlands and South Africa compared}

Generally the protection of rights can be situated between two poles, these being the political and judicial. ${ }^{9}$ In other words, who has the final say as to the protection of rights, the courts or parliament? Prior to the Second World War the emphasis rested on the political protection of rights, or the parliamentary model as it is also sometimes called. ${ }^{10}$ The supreme interpreter of human rights was the political voice of the electorate, and often only that voice. Courts were expected to apply the law and not to shape it. This was also the tradition in both the Netherlands and South Africa.

The Netherlands, under the influence of the French Revolution with its emphasis on popular legitimacy and its distrust of higher law applied by judges,

6 See generally on the this awareness and the development of the theory of rights Burkens Algemene Leerstukken 1-12, 27-45; Rautenbach and Malherbe Constitutional Law 291292; De Meij and Van der Vlies Inleiding 260.

7 Van Eikema Hommes supra n 2 at 44-45; Pierson Modern State 50-77.

8 Böckenförde supra n 4 at 155-157; Van der Schyff Concept van Democratie 553.

9 See generally Sadurski 2002 Oxford J of Legal Studies 275.

10 See Koopmans Courts 15-34 who expands on the parliamentary model by reference to the United Kingdom. 
followed a route of parliamentary supremacy.$^{11}$ The same can be said of South Africa, which drawing heavily on the Westminster and common law tradition focused on the protection of rights by private law means. ${ }^{12}$ South Africans were not protected by a bill of rights, but by private law constructions translating rights and a sovereign parliament that enjoyed full responsibility for the integrity of the laws it passed. Both systems therefore saw much faith placed in parliament as the ultimate guardian of rights. There is however a difference to be noted here.

The Netherlands with its civil law focus viewed rights very much as part and parcel of public law; this is evidenced by the piecemeal inclusion of fundamental rights in the Constitution since the nineteenth century culminating in the grand revision of $1983 .{ }^{13}$ The question centred though on who had to interpret that aspect of public law; the arrived answer being parliament. South Africa on the other hand never knew entrenched fundamental rights; constitutional law was seen as 'positive morality' under the influence of John Austin's thought and not as 'positive law'. ${ }^{14}$ The effect was essentially the same - rights were in essence political tools and not so much judicial tools.

This view, namely of rights being solely political instruments, was held for a long time in South Africa, and as is generally known, also the source of great strife. ${ }^{15}$ The white minority dominated the political apparatus and effectively the rights of the black majority for much of the country's history in the twentieth century. The racial discrimination this engendered and the consequent protests, both nationally and internationally, fired the country's democratisation from the

11 See on the French Revolution and its effect on judicial review Cappelletti Judicial Process 193-194; Brewer-Carias Judicial Review 64-67.

12 See generally on the protection of rights under common law Jayawickrama Judicial Application 98-109; Doyle and Wells Common Law 17.

13 The current Dutch Constitution is a revised version of the document that was originally adopted in 1814 bringing about the restoration after the Napoleonic era. The country has therefore not known various constitutions, but one document that sees revision from time to time. The last comprehensive revision took place in 1983. The Constitution must be distinguished from the Charter of the Kingdom of the Netherlands of 1953 that forges the union between the Netherlands, the Netherlands Antilles and Aruba. See Kortmann and Bovend' Eert Kingdom of the Netherlands 12-13.

14 See Austin Province of Jurisprudence (first published in 1832).

15 Venter supra $n 5$ at $74-79$. 
1980s onwards culminating in the constitutional settlement of the 1990s with the adoption of the interim Constitution in 1993 and the final Constitution in 1996. ${ }^{16}$ A settlement which saw rights taking a prominent place in the new order. This prominence was grounded by the fact that the courts were called to enforce rights, thereby opting for what can be termed the constitutional model instead of the parliamentary model. ${ }^{17}$ No longer were judges deemed to be the mechanical appliers of the law, but they were enjoined to investigate the constitutional legitimacy of government action affecting rights.

The Netherlands, on the other hand, has not known so much opposition to accepting the idea of the judicial review of legislation in the light of fundamental rights as was the case in South Africa. ${ }^{18}$ Instead the real question centres to a certain extent on deciding the source of the rights which are to be used as benchmarks for review, namely should one settle for national or international rights? This is explained below.

\subsection{Source of rights}

The proper protection of fundamental rights is not only a question of whether rights are to be enforced by the judiciary, but importantly also relates to where such rights are to be found. Different systems follow different rules of recognition when it comes to locating the rights to which the bearers may lay claim. Globalisation has played a large role in this respect. People not only look across national boundaries for employment and financial opportunities, but increasingly also for their rights. The Universal Declaration of Human Rights set the trend in 1948, a trend which has known an explosion in recent years when it comes to treaties guaranteeing rights. The traditional setting of rights, namely

16 The interim Constitution of South Africa (including its Bill of Rights) was adopted in 1993 and came into force in 1994, it paved the way for the final Constitution (including its Bill of Rights) which was adopted in 1996 and came into effect in 1997. References to the South African Constitution must be taken to mean the final Constitution, unless the contrary can be deduced. For a general overview see Bouckaert 1997 Stanford J of Int'l L 375.

17 See Koopmans supra n 10 at 35-62 who expands on the constitutional model by reference to the US.

18 See Van Houten Zicht op Wetgeving; Adams and Van der Schyff 2006 ZaöRV for overviews. 
national bills of rights is certainly not waning, but is faced by a competition of sorts when burgeoning international sources are taken into account.

\subsubsection{International protection}

Good governance by means of rights protection is far from being solely a national matter nowadays. This raises interesting questions as to the relation between national and international human rights regimes. These questions are solved differently from state to state, however two main possibilities can be identified. International law, including its accompanying human rights guarantees, can have direct effect in a national legal order or can enjoy effect only after having been transformed from international to national law. ${ }^{19}$ The first option, monism, is characteristic of the Dutch legal system, whereas the second, dualism, is characteristic of the South African order. This characteristic of the Dutch legal system has its foundations in unwritten constitutional law, while the Constitution on its part places a duty on the judiciary in section 94 not to apply national legal provisions where and to the extent these conflict with international law. ${ }^{20}$ International law is thus hierarchically superior to national law, including the Constitution. ${ }^{21}$

This stands in contrast to the South African position where the Constitution is always superior to international law, which in principle has to be enacted as national law before it may be applied by the courts. ${ }^{22}$ A conflict between a transformed treaty and the South African Constitution is resolved by following the latter, this is also the case when a conflict arises between the Constitution and customary international law. ${ }^{23}$ Whereas the Dutch system opts to turn to international law as its highest source of human rights, the South African

19 Jayawickrama supra n 12 at 95-97.

20 S 94 of the Dutch Constitution states that: "Legislative provisions in force within the Kingdom shall not be applicable if their application is in conflict with provisions of treaties that are binding on all persons or in conflict with resolutions adopted by international institutions." See Dölle and Engels Constitutionele Rechtspraak 51-52; Burkens et al Democratische Rechtsstaat 331.

21 Taekema (ed) Understanding Dutch Law 21.

22 An exception was created in s 231(4) of the Constitution for self-executing treaties. See Olivier 2003 TSAR 495 who argues that parliament should indicate what it regards as selfexecuting; otherwise the courts would have to determine the question.

23 S 232 of the South African Constitution. 
dispensation chooses to place its faith in the national constitution. This does not mean to say though international law is disregarded in South Africa - far from it actually. Section 39(1)(b) of the Bill of Rights enjoins courts, tribunals and fora to take international law into account when interpreting the Bill's provisions, this obligation is also not limited to binding international law. ${ }^{24}$ While section 233 of the Constitution states that courts must prefer a reasonable interpretation of legislation that accords with international law to alternative interpretations that are inconsistent with international law. In practice judicial decisions in South Africa often refer to international law for guidance, while international law is pleaded frequently in Dutch courts to trump national provisions. ${ }^{25}$ International law clearly plays an important part in protecting human rights in both countries, but in very different ways. The Netherlands prefers a direct and superior role for international law, while the South African situation calls for international law to be considered, but never at the expense of the Constitution.

\subsubsection{National protection}

The situation is also very different between the two legal systems when the role of fundamental rights guaranteed at national level is compared. The Netherlands saw a gradual development of the guarantees entrenched in the Constitution since the nineteenth century, which ultimately culminated in the constitutional revision of 1983 and the inclusion of socio-economic rights in the Bill of Rights. ${ }^{26}$ South Africa, in contrast, never knew fundamental rights provisions in its various constitutions. This met with an abrupt change in the 1990s with the onset of the country's democratisation. Both the interim and final Constitutions boasted Bills of Rights, importantly these bills were also enforceable by the judiciary. This stands in stark contrast to the Constitutions of 1909, 1961 and 1983 which did not include express bills of rights and were either silent when it came to the judiciary applying the constitution or even forbade it, thereby affirming parliamentary sovereignty.

24 S v Makwanyane 1995 (6) BCLR (CC), 1995 (3) SA 391 (CC), par 35; Rautenbach and Malherbe supra $\mathrm{n} 6$ at 42.

25 See Hovell and Williams 2005 Melbourne University LR 131.

26 See Akkermans, Bax and Verhey Grondrechten 35. 
Although the Netherlands knew a bill of rights since the nineteenth century the Constitution saw the inclusion of a bar in 1848 to the judiciary reviewing compliance with constitutional provisions, so confirming the supremacy of parliament. This prohibition, which is at present contained in section 120 , has become a standard feature of the Dutch Constitution and has survived the document's numerous revisions. ${ }^{27}$ Its effect is to prohibit the judiciary from testing whether acts of parliament comply with the rights in the Constitution or the procedure prescribed for the enactment of such laws. ${ }^{28}$ However, section 120 does not prevent the judiciary from reviewing laws of a lesser status than acts of parliament, such as delegated legislation and provincial and local ordinances, for constitutional compliance so long as such an inquiry does not implicitly review an act of parliament in the process. ${ }^{29}$ The idea was to allow the judiciary some measure of review, while still protecting parliament's primacy in passing acts. Reality, as almost always, took on a different shape. This is because the judiciary increasingly reviewed legislation, including acts of parliament, for compliance with international law, thereby denting parliament's legislative supremacy. ${ }^{30}$ One could say that international developments outpaced national recalcitrance. This again highlights a difference with the South African situation, where parliament's supremacy was decidedly broken in the 1990s and not simply watered down as is the case in the Netherlands.

This anomaly in Dutch law of judicial review in respect of international law, but only of laws of a lesser status than acts of parliament when the Constitution is at stake, has gained widespread criticism. ${ }^{31}$ For instance, a member's bill is

27 S 120 of the Dutch Constitution reads: "The constitutionality of acts of parliament and treaties shall not be reviewed by the judiciary." See Sap Netherlands Constitution 18-19; Hirsch Ballin Constitutionele Toetsing 47-67; Dölle and Engels supra n 20 at 15-20; Burkens et al supra n 20 at 184-191.

28 Hoge Raad 27 January 1961, NJ 1961, 248 (annotated by DJ Veegens); Hoge Raad, 14 April 1989, NJ 1989, 469 (annotated by M Scheltema); Van Houten supra n 18 at 41, 6873.

29 Van Houten supra n 18 at $80-85,239-241$. The idea behind this construction is that parliament has sufficient procedural guarantees and democratic legitimacy to conduct constitutional review by itself, something which is not always the case with other legislative authorities - such as government-made delegated legislation or ordinances made by decentralised authorities.

30 This was of course a consequence of the doctrine of monism.

31 See Van Houten supra n 18 at 241-256 in this regard. 
currently being considered in the Senate, after its adoption by the Lower House, which would allow the judicial review of many, mostly classical, rights guaranteed in the Constitution. ${ }^{32}$ There are however grave doubts whether the proposal will pass the Senate, after which it would have to be passed again by both houses, but this time with a qualified majority of two-thirds. ${ }^{33}$ It then seems as if the current state of affairs will remain so for quite a bit longer.

\subsubsection{Justification}

The above raises the question as to the justifiability of these very different avenues pursued in respecting fundamental rights. The one, namely Dutch, sees a wish to preserve parliament's supremacy in respect of the Constitution, but sees it broken in respect of international law; while the other, South African, chooses to subject parliament to the judicially enforced Constitution and sees international law playing only an indirect role as an interpretative aid.

It can be argued that these different routes to the protection of rights are justified by reference to their context. The strong arm of the judicial branch, as it were, was seen as necessary in South Africa in aiding the consolidation of a sound democratic system after having suffered legislative abuse for so long. ${ }^{34}$ The need was felt to ensure that an over-concentration of power in one body was to be avoided, even if such a body is democratically elected in contrast to past parliaments. The Netherlands on the other hand never knew such a

32 Tweede Kamer vergaderjaar 2001-2002, 28, 331, no 2. The bill would allow for deconcentrated review, in other words all judges would be allowed to review the constitutionality of acts of parliament and not only special constitutional judges. This in line with the judicial review of international law, which is also organised along deconcentrated lines. See also Tweede Kamer vergaderjaar 2002-2003, 28, 331, no 9; Adams and Van der Schyff supra n 18 at 399.

33 The Senate drafted a particularly negative report of the bill; see Eerste Kamer vergaderjaar 2004-2005, 28, 331, B. The report focuses on the separation of powers and reiterates that the democratically elected legislature has to take responsibility for the constitutionality of legislation and not the courts.

34 See generally Currie and De Waal Bill of Rights 8-10, who explain that constitutionalism in modern-day South Africa must entail judicial review, even though institutions such as parliament now enjoy legitimacy. This is because judicial review can serve to strengthen democracy which is one of the new dispensation's foundational values. 
decisive shift from one dispensation to another, thereby explaining its haphazard constitutional development over the years. ${ }^{35}$

However, one could still argue that judicial review of the Dutch Constitution should be allowed as a matter of principle. ${ }^{36}$ In other words, good governance decrees such a document's judicial review. Although there is much to be said for the principle, one could cast doubts on certain characteristics of the Dutch Constitution. The Constitution is a rather technical document, its human rights provisions focus on the division of power more so than on the quality of an interfering measure. For example, only one provision in the Bill of Rights, namely section 15(4) regarding the rights of detainees, provides for the principle of proportionality to be applied in measuring the justifiability of interferences with the right. ${ }^{37}$ Instead the Bill focuses on creating extensive delegation provisions in its various limitation clauses, by either allowing only parliament to limit a right or including the possibility of it delegating the capacity to other organs. ${ }^{38}$

In comparison the South African Constitution states in its general limitation clause contained in section 36(1) that a right may only be limited by a "law of general application", thereby requiring legality but not restricting the state in its delegation to other organs of the capacity to set limits to rights. The rather technical Dutch approach should, arguably, only be viewed as important guidelines for parliament when considering new legislation, instead as hard and fast rules to be applied by the judiciary. This is the case as the strict judicial review of these intricate delegation provisions, which some may even call dated relics of the nineteenth century as to the mode of limitation, may obstruct efficient administration of the state by being too formalistic.

35 See De Meij and Van der Vlies supra n 6 at 31-47 who sketch the relatively peaceful development of the Dutch state.

36 Dölle and Engels supra n 20 at 75-80.

37 S 15(4) of the Dutch Constitution holds that: "A person who has been lawfully deprived of his liberty may be restricted in the exercise of fundamental rights in so far as ['so far as' is taken to refer to a proportionality assessment] the exercise of such rights is not compatible with the deprivation of liberty."

38 For an overview of delegation in the Dutch Constitution see Burkens et al supra n 20 at 73, 78-79, 133-134; De Meij and Van der Vlies supra n 6 at 127-132. 
However, Dutch citizens on the other hand can still turn to international law for the substantive protection of their rights, an avenue which is closed in South Africa. This further difference is probably also justified. South Africa has to create and foster its own particular human rights culture in order to address its own past more so than the Netherlands, which can rely on a well developed regional system of protection in the form of the European Court of Human Rights, something which is still in its early stages in Africa. Again, the different approaches adopted in the Netherlands and South Africa can be understood, and probably accepted, by reference to each country's constitutional development and particular characteristics.

\subsection{Character of rights}

The twentieth century has known something of a rights explosion. Not only has the awareness of rights increased but also the number of rights. Whereas the nineteenth century saw a decided focus on civil and political rights, classical rights in other words, the previous century saw a shift to include socioeconomic rights. The material rechtsstaat developed a new social dimension, not only does the focus of law rest on the organisation of the state and the accompanying political rights, but also on the quality of life within that state. ${ }^{39}$ This had led to questions as to the role of the judiciary in regards to enforcing socio-economic rights.

In respect the expansion of the judicial function in South Africa in the 1990s was not limited to classical rights, but also extended to the enforcement of socio-economic rights. However this had more meaning under the final Bill of Rights of 1996 solidifying the country's transition than under the interim Bill of Rights of 1993, as the latter did not include a 'full' declaration of both classical and socio-economic rights as was the case under the final Bill of Rights. The courts have then also made use of their new powers in reviewing compliance 
with the rights guaranteed in the final Bill. For example, the well-known decision of Grootboom attracted international attention and praise as a model example of courts investigating issues related to socio-economic rights. ${ }^{40}$ In this case the applicant and others were evicted from government land on which they squatted, but they were not provided with alternative accommodation thereby rendering them destitute. The court held that the government's housing programme by not protecting those in desperate need of shelter did not adequately see to the 'progressive realisation' of the right to housing in section 26 of the Bill of Rights. ${ }^{41}$ The government was consequently called upon to provide the evicted people with emergency shelter.

Such an approach to socio-economic rights is largely unheard of in the judicial world. Courts are generally accepted as arbiters of classical rights, but socioeconomic rights are still very much the preserve of legislatures. The argument is usually raised that courts are not equipped to investigate government policy in relation to social matters and should consequently pay deference to those elected to make such policy. This is also generally the case in the Netherlands. Although there exists no bright-line rule in this regard, courts usually hold that matters related to socio-economic rights are not for them to decide, but are mere policy instructions aimed at government and not hard law. ${ }^{42}$ This reserve is far weaker when it comes to classical rights, as such rights are deemed as guaranteeing private spheres of state exclusion over which judges are competent. ${ }^{43}$ In other words, areas in which people are free to act and where the state has to withhold itself from action. This relies on the divide between action and inaction. Where the state is called upon to act, such as in the provision of socio-economic rights, the courts are reluctant to interfere; but where the state is called upon to refrain from action, such as is generally the case with classical rights, the courts are generally more inclined to investigate

40 Government of the RSA v Grootboom 2001 (1) SA 46 (CC), 2000 (11) BCLR 1169 (CC). See Malherbe 2005 ZöR 111; Klaaren Institutional Interpretation 105.

41 S 26 of the South African Constitution provides that: "(1) Everyone has the right to access to adequate housing. (2) The state must take reasonable legislative and other measures, within its available resources, to achieve the progressive realisation of this right."

42 Burkens et al supra n 20 at 138-139; Van der Roest Basisboek Recht 421; Prakke, De Reede and Van Wissen Handboek 381.

43 De Meij and Van der Vlies supra n 6 at 263. 
the matter. This dichotomy has given much fuel for an at times heated academic debate as to the judicial enforceability of socio-economic rights in contrast to classical rights. ${ }^{44}$

The purpose of this contribution is however not to repeat this debate, but to venture some thoughts on the justifiability of the status quo in South Africa in comparison to that in the Netherlands regarding the character of rights and their judicial enforceability. In other words, is the fact that socio-economic rights are generally not enforced by the judiciary in the Netherlands justified, given the outspoken judicial interest in such rights in South Africa? The answer to this question is probably yes.

Although one can on principle grounds advocate that socio-economic rights must be judicially enforced, this picture may change when the reality of a particular situation is considered. For example, the Netherlands is a highly developed country with an elaborate social welfare system. It is a society of little want in comparison to most other countries in the world. This enviable state of affairs has to date then also largely been the product of the political process. The introduction of social legislation on a large scale, starting in the 1950s, came about by political imperative, not judicial imperative. In other words, there is no general feeling in the Netherlands that socio-economic rights are not to be entrusted to parliament or that the situation will radically change were the judiciary to enforce such rights. Politicians are perceived as probably better placed to make such decisions than judges. ${ }^{45}$

South Africa on the other is undoubtedly also justified in having a judiciary which is called upon to test government policy in the socio-economic sphere. It may not be forgotten that South Africa knew a watershed moment, namely that between a society based on a supreme parliament that negated rights and a

44 See generally Vlemminx Nieuw Profiel.

45 See Burkens et al supra n 20 at 184 who explain that parliament is often perceived as being better placed to decide constitutional issues, as it is also responsible for adopting the Constitution in its guise as constitutional assembly. 
dispensation based on a justiciable supreme constitution that treasures rights. ${ }^{46}$ The South African situation given its past experience with the overconcentration of power in the legislative branch is rightfully wary of placing all its eggs in one basket as it were. Engaging the courts then seems to be a logical response to the country's history. The great social need in South Africa could certainly also be mentioned as another reason as to why not only the legislative branch of the trias politica is to be engaged, but also the judicial branch. Simply put, the social project to be embarked upon is so large and important that the courts, as co-arbiters, may serve to help government in approaching such important matters from the right perspective.

\subsection{Locus of protection}

The locus of protection refers to the notion of a centrifugal point or force of fundamental rights protection within a particular system. ${ }^{47}$ Stated differently, where is the essence or core of a system's concern for rights seated? Can a conditio sine qua non be identified without which fundamental rights protection in a particular legal system can simply not be imagined? In other words, a focal point of sorts in constituting the necessary protection of rights.

It is clear from the above exposition of fundamental rights protection in the Netherlands and South Africa that different loci are at stake when it comes to securing such protection in both systems. For instance, the South African dispensation is a clear example of a system that knows one central point or locus of fundamental rights protection, namely the Constitution. The Constitution can be seen as the source document of not only the state and its institutions, but also of fundamental rights and their enforcement. Section 2 of the document makes this clear by stating that it is -

46 New National Party of SA v Government of the RSA 19995 BCLR 489 (CC), 19993 SA 191 (CC) par 120.

47 The term locus of power is used often in literature on political science in tracing the source of political power in a state; here, however, it is used in the context of constitutional power. 
the supreme law of the republic; law or conduct inconsistent with it is invalid, and the obligations imposed by it must be fulfilled. ${ }^{48}$

When studying fundamental rights protection in South Africa, the Constitution is to be viewed not only as the starting point, but also as the destination, as its provisions have the final say so to speak. This stands quite in contrast to the Dutch system.

The locus of the protection of fundamental rights in the Netherlands is not a unitary but a composite one. Rights protection is not as focused on the Constitution and its dictates as is the case in South Africa, but is instead a joint venture between the Constitution, parliament and international law. ${ }^{49}$ As a matter of fact, the debate has not been settled as to whether the Dutch parliament derives its legislative power from the Constitution or whether it may lay claim to inherent power. ${ }^{50}$ The latter view obviously enhances parliament's standing vis-à-vis constitutional authority and dictates, thereby diluting any centrifugal force. Furthermore, although the Constitution is an important source document, the role of parliament may also not be underestimated, as constitutional rights are often interpreted by using legislation as an interpretative aid. Moreover, when interpreting constitutional rights much also centres on the parliamentary preparatory work in drafting such provisions in order to stay true to the intention of the drafters. Add to the equation the weight of international law, both the possibility to invoke such law before domestic courts and the right to lodge applications with supranational courts, and the picture of rights protection becomes decidedly varied. A number of important forces work in on such protection from different angles, often in competition or congruence with each other, while the South African system takes on the form

48 See Rautenbach and Malherbe supra n 6 at 24-25.

49 See Van der Hoeven Plaats van de Grondwet passim; Kortmann and Bovend' Eert supra n 13 at 6; Kortmann and Bovend' Eert Constitutioneel Recht 5 regarding the function and place of the Dutch Constitution in that country's constitutional law. Sap supra n 27 at 42 words it as follows: "Dutch constitutional law is not based on a single overriding principle."

50 This debate centres on $s 81$ of the Dutch Constitution, which provides that: "Acts of Parliament shall be passed jointly by the Government and the Parliament." In other words, does the provision simply restate an established fact and further outline its procedure, or does it endow parliament (and the government) with such legislative powers? 
of a neatly tailored system with the Constitution as its logical and supreme constituent inspiration.

This difference also becomes clear when both countries' court structures are considered. South Africa has a special constitutional court as final arbiter in all constitutional matters, not only in respect of lower courts bound by means of the doctrine of precedent, but also to parliament. ${ }^{51}$ The Netherlands on the other hand knows three highest domestic courts in constitutional matters, those being the Central Council of Appeal (Centrale Raad van Beroep) for civil servant matters and social security law, the Council of State (Raad van State) for administrative law and the Supreme Court (Hoge Raad) for remaining matters. ${ }^{52}$ Add to this, institutions like the European Court of Human Rights and it quickly becomes clear that the locus of protection is not particularly centralised or hierarchically structured as is the case in South Africa. This is again the product of the fact that the Netherlands is a society characterised by a gradual expansion of fundamental rights protection, instead of a dispensation wishing to make a clean and decisive break with its past like South Africa. The Netherlands therefore never knew a pressing desire or need to focus the protection of rights as much as the South African experience. The result, namely human rights protection driven by a single force in South Africa is not emulated in the Netherlands where protection is driven by a number of largely separate forces coming together for a common purpose. This is indeed an important difference between the two systems, but undoubtedly justified seeing the difference in their constitutional development.

\section{Conclusion}

There is clearly no single or perfect route to attainting the desired protection of fundamental rights. This becomes clear after having evaluated the situation in

51 S 167 of the South African Constitution. See Rautenbach and Malherbe supra n 6 at 227, 229-232.

52 S 116, 118 of the Dutch Constitution; Wet van 9 maart 1962 op de Raad van State; Wet van 18 april 1827 op de samenstelling der rechterlijke macht en het beleid der justitie; De Blois Grondslagen 81; Brenninkmeijer Judicial Organization 49-56. 
the Netherlands and South Africa. Both these countries adhere to very different views in giving shape to their dispensations. The focus should rest not so much on devising a one-size-fits-all formula, but instead on opting for what works within a particular context. One should however be careful not to lay too great a stress on context either. The protection of rights should still be sound, but tailored to meet different needs.

As to what 'sound protection' exactly entails one can be more clear. Fundamental rights rest on respect for individual freedom. Individual freedom to conduct one's private life as you choose; but also the freedom to make political choices. Political freedom ensures that democracy thrives, while personal freedom sets limits to what the democratic majority can expect from the rest of society and its members. ${ }^{53}$ The South African experience is clearly one of a long and difficult struggle for a dispensation that enables such freedom, while the Dutch experience attests more of a gradual development seeking to find a delicate balance between the need to preserve tradition and embrace change. Both systems though are faced by the same challenge, namely that of ensuring that the right balance is continually struck between their state and society in guaranteeing real freedom.

53 The ECHR held similarly in Chassagnou v France of 29 April 1999 par 112: "Although individual interests must on occasion be subordinated to those of a group, democracy does not simply mean that the views of a majority must always prevail: a balance must be achieved which ensures the fair and proper treatment of minorities and avoids any abuse of a dominant position." 


\section{Bibliography}

Adams Recht en Democratie

Adams M Recht en Democratie ter Discussie: Essays over Democratische Rechtsvorming (Universitaire Pers Leuven 2006)

Adams and Van der Schyff 2006 ZaöRV

Adams $M$ and Van der Schyff $G$ "Constitutional review by the judiciary in the Netherlands: A question of politics, democracy or compensating strategy?" 2006 (66) Zeitschrift für ausländisches öffentliches Recht und Völkerrecht 399-413

Akkermans, Bax and Verhey Grondrechten

Akkermans PWC, Bax CJ and Verhey LFM Grondrechten $3^{\text {rd }}$ ed (Tjeenk Willink Deventer 1999)

Austin Province of Jurisprudence

Austin J The Province of Jurisprudence Determined (Cambridge University Press Cambridge 1995)

Böckenförde State, Society and Liberty

Böckenförde E-W Society and Liberty (Berg New York 1991)

Bouckaert 1997 Stanford J of Int'l L

Bouckaert PN “The Negotiated Revolution: South Africa's transition to a Multiracial Democracy"1997 (33) Stanford Journal of International Law 375411

Brenninkmeijer Judicial Organization

Brenninkmeijer AFM "Judicial Organization" in Chorus JMJ, Gerver PHM, Hondius EH and Koekkoek AK (eds) Introduction to Dutch Law $3^{\text {rd }}$ ed (Kluwer The Hague 1999) 


\section{Brewer-Carias Judicial Review}

Brewer-Carias AR Judicial Review in Comparative Law (Cambridge University Press Cambridge 1989)

\section{Burkens Algemene Leerstukken}

Burkens MC Algemene Leerstukken van Grondrechten naar Nederlands Constitutioneel Recht (Tjeenk Willink Zwolle 1989)

Burkens et al Democratische Rechtsstaat

Burkens MC, Kummeling HRBM, Vermeulen BP and Widdershoven RJGM Beginselen van de Democratische Rechtsstaat $6^{\text {th }}$ ed (Kluwer Alphen aan den Rijn 2006)

Cappelletti Judicial Process

Cappelletti M Judicial Process in Comparative Perspective (Clarendon Press Oxford 1989)

Cappelletti 1992 TSAR

Cappelletti M "Judicial review of the constitutionality of state action: Its expansion and legitimacy" 1992 Tydskrif vir die Suid-Afrikaanse Reg 256266

Currie and De Waal Bill of Rights

Currie I and De Waal J The Bill of Rights Handbook $5^{\text {th }}$ ed (Juta Lansdowne 2005)

De Blois Grondslagen

De Blois M Grondslagen van het Recht (Boom Juridische Uitgevers Den Haag 2005)

De Meij and Van der Vlies Inleiding

De Meij JM and Van der Vlies IC Inleiding tot het Staatsrecht en het Bestuursrecht (Tjeenk Willink Deventer 2000) 
Dölle and Engels Constitutionele Rechtspraak

Dölle AHM and Engels JWM Constitutionele Rechtspraak (WoltersNoordhoff Groningen 1989)

Doyle and Wells Common Law

Doyle $\mathrm{J}$ and Wells $\mathrm{B}$ "How far can the common law go towards protecting human rights?" in Alston P (ed) Promoting Human Rights Through Bills of Rights: Comparative Perspectives (Oxford University Press Oxford 1999)

Hatchard et al Comparative Constitutionalism

Hatchard J, Muna N and Slinn P Comparative Constitutionalism and Good Governance in the Commonwealth (Cambridge University Press

Cambridge 2004)

Hirsch Ballin Constitutionele Toetsing

Hirsch Ballin EMH "Constitutionele toetsing van wetten als bijdrage aan de rechtsontwikkeling" in Konijnenbelt W (ed) Rechter en Wetgever (Raad van State Den Haag 2001)

Hovell and Williams 2005 Melbourne University LR

Hovell D and Williams G "A Tale of Two Systems: The use of International Law in Constitutional Interpretation in Australia and South Africa" 2005 Melbourne University Law Review 131-178

Jayawickrama Judicial Application

Jayawickrama N The Judicial Application of Human Rights Law: National, Regional and International Jurisprudence (Cambridge University Press Cambridge 2002)

Klaaren Institutional Interpretation

Klaaren J "An Institutional Interpretation of socio-economic rights and judicial remedies after TAC" in Botha $\mathrm{H}$, Van der Walt $\mathrm{A}$ and Van der Walt $\mathrm{J}$ (eds) Rights and Democracy in a Transformative Constitution (Sun Press Stellenbosch 2003) 
Koopmans Courts

Koopmans T Courts and Political Institutions: A Comparative View

(Cambridge University Press Cambridge 2003)

Kortmann and Bovend' Eert Constitutioneel Recht

Kortmann CAJM and Bovend' Eert PPT Inleiding: Constitutioneel Recht $5^{\text {th }}$ ed (Kluwer Deventer 2006)

Kortmann and Bovend' Eert Kingdom of the Netherlands

Kortmann CAJM and Bovend' Eert PT The Kingdom of the Netherlands: An Introduction to Dutch Constitutional Law (Kluwer Deventer 1993)

Malherbe 2005 ZöR

Malherbe R "The development of socio-economic rights in South Africa" 2005 (60) Zeitschrift für öffentliches Recht 111-126

Olivier 2003 TSAR

Olivier ME "South Africa and international human rights agreements: procedure, policy and practice" (Part 1) 2003 (2) Tydskrif vir die SuidAfrikaanse Reg 293-310

Olivier 2003 TSAR

Olivier ME "International human rights agreements in South African law: Procedure, policy and practice" (Part 2) 2003 (3) Tydskrif vir die SuidAfrikaanse Reg 490-511

Pierson Modern State

Pierson C The Modern State $2^{\text {nd }}$ ed (Routledge London 1996)

Prakke, De Reede and Van Wissen Handboek

Prakke L, De Reede JL and Van Wissen GJM Handboek van het Nederlandse Staatsrecht $14^{\text {th }}$ ed (Tjeenk Willink Deventer 2001) 
Rautenbach and Malherbe Constitutional Law

Rautenbach IM and Malherbe EFJ Constitutional Law $4^{\text {th }}$ ed (LexisNexis Butterworths Durban 2004)

Sadurski 2002 Oxford J of Legal Studies

Sadurski W "Judicial review and the protection of constitutional rights" 2002 (22) Oxford Journal of Legal Studies 275-299

Sap Netherlands Constitution

Sap JW The Netherlands Constitution 1848-1998: Historical Reflections (Lemma Utrecht 2000)

\section{Stern 1981 TSAR}

Stern $\mathrm{K}$ "A society based on the rule of law and social justice: Constitutional model of the Federal Republic of Germany" 1981 Tydskrif vir die SuidAfrikaanse Reg 241-250

Taekema Understanding

Taekema S (ed) Understanding Dutch Law (Boom Juridische Uitgevers Den Haag 2004)

Troper 2003 Int'l J of Constitutional Law

Troper M "The Logic of Justification of Judicial Review" 2003 (1)

International Journal of Constitutional Law 99-121

Van der Hoeven Plaats van de Grondwet

Van der Hoeven J De Plaats van de Grondwet in het Constitutionele Bestel (Tjeenk Willink Zwolle 1988)

Van der Roest Basisboek Recht

Van der Roest OAP (ed) Basisboek Recht (Wolters-Noordhoff Groningen 2006) 
Van der Schyff Concept van Democratie

Van der Schyff G "Het Concept van Democratie in het EVRM" in Adams M and Popelier P (eds) Recht en Democratie (Intersentia Antwerpen 2004)

Van Eikema Hommes 1978 TSAR

Van Eikema Hommes HJ "De materiële rechtsstaatidee" 1978 Tydskrif vir die Suid-Afrikaanse Reg 42-52

Van Houten Zicht op Wetgeving

Van Houten MLP Meer Zicht op Wetgeving: Rechterlijke Toetsing van Wetgeving aan de Grondwet en Fundamentele Rechtsbeginselen (Tjeenk Willink Zwolle 1997)

Venter Constitutional Comparison

Venter F Constitutional Comparison: Japan, Germany, Canada and South Africa as Constitutional States (Juta Cape Town 2000)

Vlemminx Nieuw Profiel

Vlemminx F Een Nieuw Profiel van de Grondrechten: een Analyse van de Prestatieplichten ingevolge Klassieke en Sociale Grondrechten $3^{\text {rd }}$ ed (Boom Juridische Uitgevers Den Haag 2002)

Zoethout Rechtsstaat

Zoethout C "Wat is de Rechtsstaat? Een reflectie op rechtsstatelijke beginselen voor Wetgever, Bestuur en Rechter" in Van Ommeren FJ and Zijlstra SE (eds) De Rechtsstaat als Toetsingskader (Boom Juridische Uitgevers Den Haag 2003)

\section{Register of legislation}

\section{The Netherlands}

Constitution of the Netherlands 30 March 1814

Charter of the Kingdom of the Netherlands 28 October 1953 
Wet van 9 maart 1962 op de Raad van State

Wet van 18 april 1827 op de samenstelling der rechterlijke macht en het beleid der justitie

\section{South Africa}

Constitution of the Republic of South Africa Act 200 of 1993

Constitution of the Republic of South Africa 1996

\section{Register of cases}

Council of Europe

Chassagnou v France of 29 April 1999 (ECHR)

\section{The Netherlands}

Hoge Raad 27 January 1961 NJ 1961, 248 (annotated by DJ Veegens)

Hoge Raad 14 April 1989 NJ 1989, 469 (annotated by M Scheltema)

\section{South Africa}

Government of the RSA v Grootboom 2001 (1) SA 46 (CC), 2000 (11) BCLR 1169 (CC)

New National Party of SA v Government of the RSA 19995 BCLR 489 (CC), 19993 SA 191 (CC)

S v Makwanyane 1995 (6) BCLR (CC), 1995 (3) SA 391 (CC)

\section{Register of treaties, international documents and parliamentary papers}

Eerste Kamer vergaderjaar 2004-2005, 28, 331

Tweede Kamer vergaderjaar 2001-2002, 28, 331

Universal Declaration of Human Rights 1948

\section{List of abbreviations}

ECHR European Court of Human Rights

par paragraph(s)

$\mathrm{s} \quad$ section(s) 